\title{
Learner motivation in the EFL classrooms: Voices from a Bangladeshi university
}

\author{
Takad Ahmed Chowdhury ${ }^{1 *}$, Sarbani Roy $^{2}$, and Muhammad Kamarul Kabilan ${ }^{1}$ \\ ${ }^{1}$ School of Educational Studies, Universiti Sains Malaysia, Malaysia \\ ${ }^{2}$ Government P.C. College, Bagherhat, Bangladesh
}

\begin{abstract}
English proficiency is considered a door opener almost in any field anywhere in the world, yet all the attempts to improve effectiveness of teaching and learning of English language in Bangladesh seem to fail over decades. Although poor learning motivation is counted as a key aspect why students do not hold their attention to their English classes and make use of their capabilities to understand and learn cognitively, there has been a very limited number of studies in Bangladeshi context to deal with this critical issue. This mixed method study attempted to identify the sources of motivation for attending English classes of the 1st year undergraduate students at a Bangladeshi university. Quantitative data was collected using two close-ended questionnaires from 50 randomly selected Bangladeshi tertiary level English language learners and 10 teachers. The student questionnaire was developed by adding three items with the ten items adapted from Clement et al. (1994) and the teachers' questionnaire was developed and administered to follow up the findings from the student participants. For a more complete analysis, structured interviews were conducted with 10 purposively selected students. The results indicated lack of intrinsic motivation among the learners, and based on the existing literature, the study recommended the way outs to improve motivation of the non-performing learners. The recommendations included, shifting from exam-oriented assessment system, teachers' reflection of their own teaching practices, redesigning course curricula based on learning need and learners' expectations, ensuring easy access to the latest educational facilities, and encouraging the roles of students and their peers to develop learners' motivation and foster their autonomous learning opportunities. Finally, the limitations are drawn and suggestions for further research are provided.
\end{abstract}

Keywords: Bangladeshi EFL classroom; learner autonomy; learner motivation; tertiary level; needs analysis

\begin{tabular}{|c|c|c|}
\hline $\begin{array}{l}\text { First Received: } \\
\text { 10 January } 2021 \\
\text { Final Proof Received: } \\
15 \text { May } 2021\end{array}$ & $\begin{array}{c}\text { Revised: } \\
22 \text { February } 2021\end{array}$ & $\begin{array}{c}\text { Accepted: } \\
\text { 4 March } 2021 \\
\text { Published: } \\
\text { 31 May 2021 }\end{array}$ \\
\hline $\begin{array}{l}\text { How to cite (in APA style): } \\
\text { Chowdhury, T. A., Roy, S., \& Kabil } \\
\text { classrooms: Voices from a Bar } \\
\text { Linguistics, } 11(1), 221-232 \text {. ht }\end{array}$ & $\begin{array}{l} \\
\text { M. K. (2021). Lea } \\
\text { ladeshi university. I } \\
\text { ://doi.org/10.1750s }\end{array}$ & $\begin{array}{l}\text { notivation in the EFL } \\
\text { esian Journal of Applied } \\
\text { v11i1.34618 }\end{array}$ \\
\hline
\end{tabular}

\section{INTRODUCTION}

English is not only the most powerful language used by the humankind, it is also the lingua franca of the globalized world that holds central role in communication, education, science and business (Melitz, 2018). This language is used by $85 \%$ of the international organizations as one of their working languages and over $80 \%$ of academic journals are written in English (Cambridge English Language Assessment, 2016). English proficiency is

*Corresponding Author

Email: takad@student.usm.my considered a door opener almost in any field anywhere in the world. No surprise that Bangladesh is increasingly inclining towards enhanced English policy to stand on good ground in the country's development context (Hamid \& Erling, 2016). In the recent past, international development partners are also financing language planning initiatives in Bangladesh that aim at improving and/or expanding English language education ever more (Erling, 2017; Hamid, 2011; Hamid \& Erling, 2016). 
English language courses are taught at all levels of educational institutions in Bangladesh as a compulsory subject. In spite of this, studies make it clear that the teaching and learning of English in Bangladesh are not bringing much success (Alam, 2018; Azam \& Tatsuya, 2018; Rahman et al., 2019).

Studies in English as a Second Language (ESL) or English as a Foreign Language (EFL) increasingly recognized motivation as an important factor for learning success, and consistently link language learners' positive engagement and motivation to both qualitative and qualitative learning outcomes (Anderman, 2020; Anjomshoa \& Sadighi, 2015; Botvinick \& Braver, 2015; Gardner, 2010; Hornstra et al., 2015; Irvin et al., 2007; Jianfeng et al., 2018). Kolb (1984) theorizes one of the most influential learning cycles, stating that:

Learners, if they are to be effective, need four different kinds of abilities-concrete experience abilities (CE), reflective observation abilities (RO), abstract conceptualization abilities (AC), and active experimentation (AE) abilities. That is, they must be able to involve themselves fully, openly, and without bias in new experiences (CE). They must be able to reflect on and observe their experiences from many perspectives (RO). They must be able to create concepts that integrate their observations into logically sound theories (AC), and they must be able to use these theories to make decisions and solve problems (AE) (cited in Morris, 2020 p. 1065).

Learning is an interactive process where attention, memory, language, processing and organizing, writing, and higher order thinking interact with each other as well as with emotions, classroom climate, behaviors, social skills, teachers and family (The Center for Development and Learning, n.d.). The dynamic process of learning and knowledge construction is explained to take place through interplay of an individual's autopoietic and self-organized cognitive and social systems, where the cognitive systems maintain themselves by continuing their own operations based on an individual's prior understanding and the social systems depend on communication (Kimmerle et al., 2015).

\section{Figure 1}

The Dynamic Process of Learning and Knowledge Construction (Kimmerle et al., 2015 p. 128)

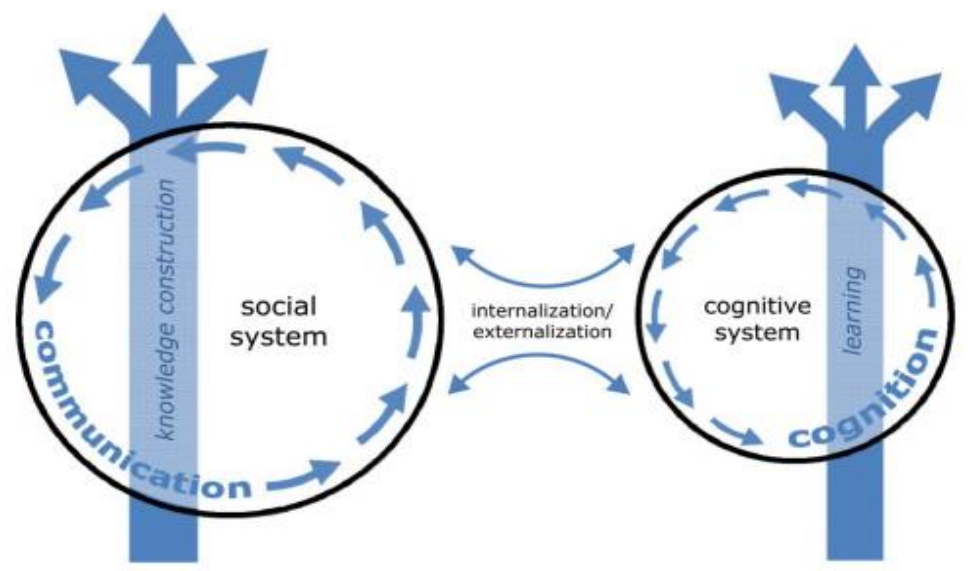

It is acknowledged by both EFL/ESL researchers and educational psychologists that motivation plays a key role in the set of functions in the process of learning and knowledge construction. Several decades of studies to explain the mechanism by which cognitive process and executive function interact recognize the relevance of motivational factors in the process of learning (Anderman, 2020; Botvinick \& Braver, 2015; Gardner, 2010; Green et al., 2017; Riswanto \& Aryani, 2017; Ryan \& Deci, 2020). Therefore, motivation plays a crucial element for a learner's deep engagement and self-investment in learning activities.

Motivation is defined as an internal process of an individual that activates, guides and maintains their observable behavior for moving towards achieving a goal (Baron, 1996; Wade \& Tarvis, 1998, cited in Loganthan \& Zafar, 2016). MacIntyre et al. (2001) maintains that, motivation is an attribute that describes the psychological qualities that drive a person towards accomplishment of a particular task. Gardner (2001, cited in Lai, 2013) observes that, motivation includes three elements, namely effort, desire and positive effect. Referring that a person's environment influences their motivation to select and achieve his goals, Dörnyei and Schmidt (2001, cited in Lodhi et al., 2019) defines motivation as the direction and magnitude of human behavior. Brown (1994) asserts that,

Motivation is probably the most frequently used catch-all term for explaining the success or failure of virtually any complex touch. It is easy to figure that success in a task is due simply to the fact that someone is 'motivated'. It is easy in second language learning to claim that a learner will be successful with the proper motivation. Such claims are of course not erroneous, for countless studies experiments in human learning have shown that motivation is a key to success. (p. 152) 
Motivation has been classified into integrative and instrumental types. Integrative motivation implies learning of a language with a view to participating in the culture of its people while instrumental motivation means learning of the language for job or other useful purposes (Ellis, 1994; Gardner \& Lambert, 1972). On the other hand, Ryan \& Deci (2000) identified motivation into intrinsic and extrinsic types. Their study explained that learners can be called intrinsically motivated when they participate in their learning activities with genuine love for the subject matter. Such motivation can influence them to stick with their learning despite the issues are intricate or complicated, gaining insight from their slips or mistakes in the learning process. Extrinsic motivation, conversely, implies the activity of learning driven by anticipated reward or punishment, like passing the examination or getting good marks (cited in Ryan \& Deci, 2020). However, Ellis (1997) suggested that different types of motivation should be seen as complimentary rather than as distinct and oppositional and a learner can be motivated in more than one type at the same time depending on the learning context or task. He also noted that, since learning aptitude depends on the cognitive abilities involved in successful second/foreign language acquisition, motivation involves the attitudes and other relevant factors that determine the degree of efforts of the learner in learning the language.

Although the issue of motivation has not been widely explored in Bangladeshi context, some researchers conducted valuable studies on the topic. Rahman (2005) carried out a study to find out attitude and motivation of undergraduate students for learning English at a Bangladeshi private university. Based on responses through a survey questionnaire followed by a semi structured interview of 94 undergraduate students, he concluded that the learners learn from integrative motivation focusing on the functional role as required. However, his assertion of elevated standard of English and essentially need-based language syllabi of Bangladeshi private universities were unsubstantiated by later studies including Chowdhury and Haider (2012), Haque (2017), and Khan (2019). Therefore, it was a long-standing requirement to investigate into the issue to explain poor performance of tertiary level Bangladeshi EFL learners. Quadir (2017) in her qualitative study, attempted to identify the sources of demotivation of Bangladeshi English language learners at their higher secondary (HS) level and impacts of those demotivators on their performance at university studies. She indicated seven demotivating factors for Bangladeshi HS English language students and made recommendations based on her findings. Conducting study on other levels of learners would certainly help in presenting a more complete view.
Saha (2017) conducted an important study based on narrative reflections from four EFL teachers from three Bangladeshi universities on the factors causing learners' unmotivation in their writing classes. In the same study, he also shared strategies for handling unmotivation in their writing class. Since the study reported unmotivating factors related to one particular language skill, there remains a scope for studies on the problem of motivation among the Bangladeshi tertiary level EFL learners on studying English language in general. The present study aimed to fill this gap by investigating into the problem of motivation and self-investment of Bangladeshi EFL learners for attending English language classes, and provide recommendations to deal with poor motivation of the non-performing learners. Therefore, the current study addresses the following two overarching questions,

1. What are the motivations of the EFL students at a Bangladeshi university for attending their language classes?

2. What can be done to improve motivation of the non-performing learners?

\section{METHOD}

This study used a mixed methods design. The researchers performed quantitative survey among students and teacher participants to answer the first research question. To better understand the research problem, the information collected through the two survey questionnaires was validated by student interviews. This combination allowed the researchers for more complete analysis. On the basis of the findings of the above, the researchers developed answer to the second research question by reviewing relevant literature.

\section{The survey}

Surveys through questionnaires help researchers across the disciplines to find answers to their specific and significant research questions (Taherdoost, 2019). The survey was conducted on the basis of two questionnaires - a questionnaire for the students and a questionnaire for the teachers. With a broader objective to understand the factors responsible for generally poor show of tertiary level Bangladeshi students in English, the two questionnaires of this study were specifically aimed at looking for their reasons to attend their English language classes.

\section{Research participants}

As this study aims to enquire into Bangladeshi EFL students' motivation for learning English who attend their mandatory English language classes for their tertiary education, it is pertinent to consider the general background and English proficiency of the participants. All the 50 students that responded to the survey were randomly selected from a university 
located in Dhaka, the capital city of Bangladesh. Among them 23 respondents were female and 27 of them were male aged between 18 and 20 . They were enrolled in the first year of their undergraduate courses when attending two to three English language courses are mandatory for them (Quadir, 2017; Riya \& Kabir, 2019). They came from different areas of the country, including the city where their university is located, after completing their Higher Secondary level of education under national curriculum, mostly in Bengali version.

There were 10 respondents in the teachers' questionnaire. All of them were English language teachers at the research site university. They all have at least Bachelor of Arts and Master of Arts in English degrees from well-known universities of Bangladesh with two of them completed their $\mathrm{PhD}$ degrees. Their teaching experience ranges between 1 and $10+$ years.

\section{Instruments}

The two questionnaires used in the study to obtain the required information were developed by the researchers. The students' questionnaire was prepared by adding 3 items with the 10 items adapted from Clement et al. (1994) which was later used by Purmama et al. (2019). Therefore, it consisted of 13 items, each of which was followed by a four-point Likert scale e.g., strongly agree, agree, disagree, and strongly disagree.

Before developing the students' questionnaire, the researchers made some literature search and conducted informal conversations with most of the participants to elicit opinions regarding their enthusiasm and motivation to attend classes of their mandatory English language courses. They compiled the opinions and prepared a draft questionnaire, where most of the items matched with Clement et al. (1994). The researchers further discussed among themselves and made some revisions for validity, common understanding, and more clarity in language.

The teachers' questionnaire consisted of closed-ended basic opinion questions (Lavrakas, 2012) on 5 issues to find out where they stand on the points based on their teaching experience and knowledge. For each question, they were given 3 options to select from. The points mentioned in the teachers' questionnaire transpired from a Focused Group Discussion (FGD) on zoom virtual platform prior to conducting the teacher survey.

\section{Interview}

Interview is a way to elicit information on a specific topic directly from the source through a series of questions and answers in real time to know further behind the responses of a survey questionnaire. Thus, it confirms, clarifies and enriches data of a study. In this study, the researchers used a set of structured interview questions where each respondent was asked the same questions in the same way to avoid the breadth of the topics of conversation and to collect relevant data in a short period of time. They conducted individual online interviews of 10 purposively selected students from the survey participants based on their availability and willingness.

The questions for the interview were prepared by, first, listing the topics related to the research questions of this study. Then the initial list was pared down by cutting topics that seem redundant. Most of the interview questions included follow-up questions to ask for more information. Feedback about the listed topics and questions was taken from two colleagues who are lecturers of English at the same university. Then, one pilot interview was conducted with a volunteering student which helped the researchers reword, drop or extend some of the interview questions. The finalized interview schedule consisted of five questions (Appendix).

\section{Procedure}

The researchers sent out both the questionnaires to the students and teachers concerned through their emails. They were informed in clear terms about the purpose of the study and were assured of anonymity. They were confirmed that their answers for any of the questions would not be revealed and would only be used for the purpose of research. The researchers also made sure that the findings of the research will be made accessible to them. After calculating the collected data in percentage, it has been described, summarized and presented in tables.

When the survey was completed, the researchers selected 10 students from among the survey participants for individual online interviews based on their availability and desire to participate. Both the authors used Google Meet, a video conferencing service from Google, and conducted five individual interviews each following preset timetables. The interviews were recorded and transcribed. Each interview session lasted between 12 and 20 minutes and all the 10 interviews yielded about 5,000 words of data. The researchers reread the transcribed data and coded it based on emerging themes and patterns by identifying recurring ideas. Finally, the most relevant categories to the research questions were separated and presented in the findings of the study.

\section{FINDINGS}

The findings are presented in the following order: the data collected through the responses from the students' questionnaire, findings from the teachers' questionnaire, and finally, the interview data. Since both the responding students and the teachers of the questionnaires had to send their responses through email, they enjoyed a better scope to think well and register their answers without any fear or prejudice. 
This helped prevent response bias especially of the student participants by ensuring them a more favorable 'context effect' (Vésteinsdóttir et al., 2019) than a face-to-face classroom setting in front of their teacher. In cases of the interviews, the participants were given opportunity to warm up to the interview and to feel relaxed speaking with the researcher.

Results from the students' questionnaire:

Results from the students' questionnaire have been presented in Table 1.

Table 1

Results from the Students' Questionnaire

\begin{tabular}{|c|c|c|c|c|c|}
\hline No. & I attend my English classes because... & $\begin{array}{l}\text { Strongly } \\
\text { Agree }\end{array}$ & Agree & Disagree & $\begin{array}{l}\text { Strongly } \\
\text { Disagree }\end{array}$ \\
\hline 1. & I really like learning English & $12 \%$ & $22 \%$ & $28 \%$ & $38 \%$ \\
\hline 2. & I will be able to know new people from different parts of the word & $12 \%$ & $36 \%$ & $38 \%$ & $10 \%$ \\
\hline 3. & I like to learn foreign languages & $24 \%$ & $22 \%$ & $18 \%$ & $36 \%$ \\
\hline 4. & I will learn English speaking and writing as an educated person & $34 \%$ & $12 \%$ & $18 \%$ & $36 \%$ \\
\hline 5. & I want to be more knowledgeable & $30 \%$ & $12 \%$ & $10 \%$ & $48 \%$ \\
\hline 6. & I want to broaden my outlook & $26 \%$ & $8 \%$ & $26 \%$ & $40 \%$ \\
\hline 7. & I may need English later (for job, study etc.) & $38 \%$ & $26 \%$ & $20 \%$ & $16 \%$ \\
\hline & $\begin{array}{l}\text { I want to understand films, videos, and television or radio } \\
\text { programs that uses English language }\end{array}$ & $22 \%$ & $26 \%$ & $28 \%$ & $24 \%$ \\
\hline 9. & I want to be able to read English books, newspapers or magazines & $20 \%$ & $28 \%$ & $30 \%$ & $22 \%$ \\
\hline 10. & I want to go abroad where skills in English is essential & $24 \%$ & $26 \%$ & $28 \%$ & $24 \%$ \\
\hline 11. & I want to pass my examinations & $54 \%$ & $22 \%$ & $14 \%$ & $10 \%$ \\
\hline 12. & I enjoy learning English through my classes & $14 \%$ & $18 \%$ & $36 \%$ & $32 \%$ \\
\hline 13. & $\begin{array}{l}\text { I will gain enough language skills for easy access to higher } \\
\text { education abroad }\end{array}$ & $16 \%$ & $18 \%$ & $28 \%$ & $38 \%$ \\
\hline
\end{tabular}

As in the Table 1 shown above, the highest number of respondents agreed or strongly agreed that they attended their English language classes because they wanted to pass their examinations (ref: item number 11). A big number of the respondents agreed or strongly agreed that they attended their classes because they might need English later for their study or job purposes (ref: item number 7), although majority of them were not confident that their university English courses would sufficiently equip them with the language skills needed for easy access to higher education abroad (ref: item number 13). Items like being able to know new people from different parts of world (ref: item number 2), understanding films, videos, and television or radio programs that uses English language (ref: item number 8), reading English books, newspapers or magazines (ref: item number 9) were triggers for more or less half of the respondents. Remarkably, the smallest number of respondents concurred that they enjoyed learning English through their classes (ref: item number 12), whereas only a slightly greater number of it reported that they liked learning English (ref: item number 1).

\section{Results from the teachers' questionnaire:}

The findings of the survey questionnaire for the teachers, which was administered to authenticate the findings of the students' responses as well as to extract their perspectives, have been presented in Table 2.

Table 2.

Results from the Teachers' Questionnaire

\begin{tabular}{lll}
\hline \multicolumn{1}{c}{ Questions } & \multicolumn{1}{c}{ Answers } & $\%$ \\
\hline How long have you been teaching English? & 1-5 year & $30 \%$ \\
& 6-10 years & $40 \%$ \\
& Above 10 years & $30 \%$ \\
\hline Select the type of class that you conduct & Teacher-centered & $30 \%$ \\
& Learner-centered & $30 \%$ \\
& A bit of both & $40 \%$ \\
\hline Select the range of percentage of your students in your & $70 \%-100 \%$ & $40 \%$ \\
class who put enough effort into learning & $40 \%-70 \%$ & $30 \%$ \\
& $0-40 \%$ & $30 \%$ \\
\hline Select the reason of reluctance of the non-participating & Classroom activities do not contribute to final grading & $40 \%$ \\
students & Lack of variety in the activities & $30 \%$ \\
& Their fear of English & $30 \%$ \\
\hline Uninteresting English classes result from... & The teachers' compulsion to finish the syllabus & $50 \%$ \\
& The teachers' inability to infuse passion, playfulness & $30 \%$ \\
& and creativity into their classes & $20 \%$ \\
\hline
\end{tabular}


As presented in the Table 2, 70\% of the participating teachers have more than 5 years of teaching experience. Although $40 \%$ of teachers stated that they conducted a mixture of teachercentered and learner-centered classes, a similar number of them thought that $70 \%$ to $100 \%$ of their students do not put enough effort into the learning during their classes. Among the tree reasons students remained reluctant $40 \%$ of the responding teachers opined that they remained non-participant because classroom activities do not make any contribution to their final grading, while two other given options namely, lack of variety in the classroom activities and students' fear of English language were selected by $30 \%$ each. motivated and active in most of the classroom activities. The greatest number of respondents to the teachers' questionnaire think that uninteresting English classes result from their compulsion to complete the syllabus.

\section{The interview data}

The most prominent themes emerged from the interview were (1) the students' hopes, efforts, needs as well as their immediate and future goals; (2) their attitudes towards learning English in general and the courses taught; (3) Their external and internal influences; and, (4) Teachers' personality, instruction, and teaching materials.

These themes were simplified to the most relevant categories based on relevance to the research questions. The findings are presented below.

\section{Attitudes and expectations}

One of the categories established through the process of the analysis was the students' attitudes towards learning English and the courses at the university. Although they generally expressed that English language skill is useful for their future career or academic endeavors, their opinions varied about the reasons they attended their English courses. The following direct quotes are taken from the interviews:

The main reason I attend classes is I aspire to do well in my examinations. My family spends a big amount on my education, and my good performance will make them happy. (S/1)

I have always been regular in my classes at my school and college. It is important to attend classes for clearer idea about the question pattern and topic outlines of the examination. ( $\mathrm{S} / 2)$

English language skills can enhance my chance to get a good job....all the good companies want applicants who are good in English (S/4)

All our books are in English. We need to submit our assignments, write the answers to the examination questions in English. (S/5)
I want to study abroad. They require a good ability in English. I will always need English skills. (S/6)

A strong grasp of English is the key to knowledge. I must be good in English so that I can read good books with ease. $(\mathrm{S} / 8)$

Therefore, while the majority of respondents attended classes to score higher in their examinations, some of them attributed it to their future goals. Thus, their immediate and future goals overlapped.

\section{Trust and feeling}

Another relevant category identified was the students' trust and views about their English language courses in fulfilling their expectations. The motivation of the students generally depends on their confidence on the courses. As evidenced, they are confused regarding the extent the courses are likely to fulfill their expectations. Although the students initially kept neutral, they gradually became more explicit on their need and efforts to make special attempts despite attending their English language courses. Following are examples of their perplexity:

I also take an online English language course with the British Council to spend more time with English-language content. (S/2)

In our second semester, we learn how to write cover letters, CVs, memos, and reports. Instead of having to learn them all in our first year, I wish we were given an extra course in the final year to learn these job skills because we may unlearn everything through the years. $(\mathrm{S} / 4)$

I wish I could more improve in writing and speaking. I now understand the grammar much better, but I am still nervous when I am asked to speak anything. I must also widen my vocabulary. (S/6)

After graduation, I will upskill in English and prepare myself so that I can score in the standardized international tests like IELTS, TOEFL or GRE for admission. (S/9)

\section{Learning environment, teaching materials and teachers}

The students continued to say that they initially failed to deal with their online classes. They also had issues with their computers and internet access.

I enjoy meeting my classmates and teachers. I like talking to them, and doing interesting things together. I hate the interruptions like slow internet or distorted audio sound. I would always speak more in my real classroom. (S/5)

In the beginning it was really difficult when I was using my old mobile phone. My family bought me a new laptop after five weeks of classes. The internet is sometimes very slow here. $(\mathrm{S} / 10)$ 
The respondents had mixed feelings regarding the course materials, where their criticisms mostly focused on the course structure and volume of materials. They were generally open about what they enjoyed and did not.

Our books and handouts are excellent, with plenty of explanations and facts. However, I believe the materials are excessive for a semester. (S/1)

It's wonderful that our teachers now upload their recorded lectures. We can watch any lecture again after our class. I appreciate this. (S/4)

The materials are too extensive, and the number of topics are too many. $(\mathrm{S} / 6)$

Our coursebooks are large and valuable. It may remain useful even after completion of our courses. (S/9)

Although the vast majority of them praised their teachers' personality, some of them also expressed the view that they cannot always approach their teacher with any problem.

Our teacher is very punctual. But I feel uneasy talking to her in the class. $(\mathrm{S} / 1)$

She speaks English in a very good accent. I wish I could speak like her. But I am always very nervous. $(\mathrm{S} / 3)$

He has very good knowledge on the topics and lectures very well. Sometimes I fail to understand his lectures. $(\mathrm{S} / 5)$

My teacher is very strict. We cannot think of missing her class. (S/7)

Our teacher is serious and experienced. But sometimes he is distracted with other duties. (S/8)

Actually, we have many topics in the course. I wish we had more classes to complete all the topics well. $(\mathrm{S} / 10)$

\section{DISCUSSION AND RECOMMENDATIONS}

The results reported in the findings generally suggest that the students attending English language courses at tertiary level in Bangladesh noticeably lack intrinsic motivation. This certainly works as a negative influence to achieve their language learning objectives because a great many researchers attribute poor achievement of language proficiency of the learners to their lack of motivation to learning (Jianfeng et al., 2018; Khonamri et al., 2020; Lathif, 2017; Liu, 2015; Mallik, 2017; Nguyen \& Walkinshaw, 2018; Nurbaety \& Hartini, 2020; Quadir, 2017; Saha, 2017).

The findings from both the quantitative and qualitative data report that the maximum number of students' attend their English language classes to be able to pass their examinations. This examination- oriented assessment system was confirmed by the responding teachers in the teachers' questionnaire by confirming that the students remained reluctant in the classroom activities because they did not contribute to their final grading. This finding exposes that the examination-based assessment system is largely responsible for the current situation that is needed to reform. There is no denying that introducing proper assessment system is a challenging task (Chowdhury, 2020), but this issue demands to be appropriately addressed to facilitate meaningful learning of the students and ensure them happy classroom environment. Understandably, the current study reveals that very few of the participants enjoy attending their English classes or love to take part in all the classroom activities because their main concern remains on the results or grades than the process of learning. In the same way, the teachers' priority has to remains in completing the syllabi not in making learning fun and motivating the students. In fact, wealth of research manifest downsides of examinationoriented education and assessment system for students and teachers alike that kill their creative abilities (Emler et al., 2019; Kirkpatrick \& Zang, 2011; Zhao, 2020). Through their use of assessment, teachers can improve or kill students' learning motivation more easily and more permanently than through any other methods (Stiggins, 2001, cited in Harlen, 2012). Therefore, an assessment system that motivates the students to learn rather than challenges them to compete for good grades is essential (Harlen, 2012).

According to the findings of the study, there is no evidence that the course teachers are interactive, innovative or student-centered. Since a positive learning environment is strongly connected to the role of the teacher and effect of their instruction, they need to reflect, evaluate and analyze their teaching practices, to develop innovative learning environment through more effective social engagement (Muslim et al., 2020). Their role can operate as a strong external motivation for the learners to influence their intrinsic motivation and learner autonomy (Hornstra et al., 2015). A reflective teacher can inspire reflective learning and ensure a participatory, student-centered teaching to promote awareness among students to invest their total faculties into their own learning by nurturing positive qualities of to improve student performance (Khan \& Rahaman, 2017; Soberg, 2018).

Moreover, the results of the current study depict the participants' lack of confidence in the courses in equipping them with the language skills needed for important purposes such as access to higher education abroad, which requires significant attention to make the courses more effective. Reducing the mismatch between teaching and learning approaches is crucial in language learning (Allwright \& Baily, 1991 cited in Baleghizadeh \& 
Karamzade, 2017). Studies continue to prove the significance of well-designed course curricula based on proper assessment of students' learning needs for more successful language education (Chowdhury \& Haider, 2012; Haque, 2017; Mamun \& Rahman, 2017). Learners are driven by enhanced motivation in order to satisfy their learning needs because expectations of need fulfillment yield a positive and energizing mindset which is manifested in their work behavior (Green et al., 2017). Therefore, the courses should be redesigned giving analysis of the learners' needs due priority. This will help them recognize and acknowledge reasons for learning, and thus reinforce their motivation to enjoy their classes.

The Covid 19 pandemic continues to affect the world and exponentially changing the education scenario we once knew. Mass closure of the educational institutions as an aftermath of the pandemic is forcing teachers to embark on emergency remote teaching with or without much preparation (Khan et al., 2020; UNESCO, 2020). Educators all around the globe have been forced to rethink about more innovative ways to deliver an education that is driven by students, more oriented toward purpose and meaning, and more global (Zhao, 2020). Therefore, redesigning curricula to suite remote teaching system with practical strategies for making online classes more motivating and effective has become crucial than ever before. It has become essential to ensure enhanced multilateral cooperation for expanding access to technology and training, adapting pedagogical strategies and reforming assessment modalities (Khan et al., 2020). Major investment in digital infrastructure as the government's goal of nation building in the $21^{\text {st }}$ century world of endless knowledge and communication can continue, as the use of technology is the way forward for the education sector. While technology alone will not be the solution for education in the pandemic and post pandemic world, it is clear that no solution will work without technology. Ensuring easy access to facilities generate motivation among the students and teachers alike to perform better (Riswanto \& Aryani, 2017).

In addition, more studies like Quadir (2017) and Saha (2017) can be conducted to identify the key sources of Bangladeshi English language learners' poor motivation to find ways to improve their motivation. A motivated language learner forms a deeper personal connection to what they learn and how they learn which positively influence on metacognition and learner autonomy (Liu, 2015; Soberg, 2018). It is therefore recommended that a strong language education system in Bangladesh is ensured to safeguard the responsibility of the teachers (Kaur, 2014; Nguyen \& Walkinshaw, 2018), reformation of the course curricula and assessment system based on learning needs
(Chowdhury \& Haider, 2012; Emler et al., 2019; Kirkpatrick \& Zang, 2011), provision of necessary environment and infrastructure (Cohen \& Bhatt, 2012; Lodhi et al., 2019), and encourage the roles of students and their peers (Kaur, 2017; Kuyyogsuy, 2019; Mak \& Wong, 2017) to develop learners' motivation and foster their autonomous learning opportunities.

\section{CONCLUSION}

In this study, we sought to investigate into the problem of motivation and self-investment among Bangladeshi tertiary level learners in their EFL classes. The results indicate existence of poor intrinsic motivation among majority of the students in the context of the study, the solutions to which are complex and challenging. Therefore, this study recommended the research-informed approaches that should be taken by the teachers, curriculum developers, institutional authorities, and the government to improve motivation and ensure learning progress. The main recommendations were, to shift from the current exam-oriented assessment system, teachers' reflection of their own teaching practices, redesign the course curricula assessing needs and expectations of the learners, ensure easy access to the latest educational facilities, and encourage the roles of students and their peers to develop learners' motivation that can foster learner autonomy. This study is significant as it adds to the existing body of literature on a pertinent issue in Bangladeshi ELT context. The study aspires to lead the way for future researchers to conduct further studies on each suggested action and their impact to improve learning motivation for effective learning.

Finally, few limitations of the study may be considered. Although this study is carefully prepared to assess the level of motivation among tertiary level Bangladeshi EFL learners based on the data collected from randomly selected student and teacher respondents, and a structured interview of the students, more elaborate questionnaires with a greater number of respondents from more institutions could not be covered due to time constraints. Adding classroom observation for interaction analysis would also further validate the findings of the study. Therefore, future studies may reassess the findings on different methodological lens, covering more institutions and centralizing more on different techniques to improve motivation and self-investment in the EFL classroom.

\section{REFERENCES}

Alam, F. (2018). Revisioning English studies in Bangladesh in the age of globalisation and ELT. In R. Chowdhury, M. Sarkar, F. Mojumder, \& M. M. Roshid (Eds.), Education in the Asia-Pacific Region: Issues Concerns 
and Prospects (Vol. 44, pp. 241-261).

Springer Singapore.

https://doi.org/10.1007/978-981-13-0708-9_13

Anderman, E. M. (2020). Achievement motivation theory: Balancing precision and utility. Contemporary Educational Psychology, 61(April), 101864. https://doi.org/10.1016/j.cedpsych.2020.10186 4

Anjomshoa, L., \& Sadighi, F. (2015). the Importance of motivation in second language acquisition. International Journal on Studies in Second Language and Literature (IJSELL), 3(2), 126-137. www.arcjournal.org

Azam, M. G., \& Tatsuya, K. (2018). A qualitative study of English teaching in Bangladesh: A case study of madrasa education. US-China Education Review, 8(3), 106-122. https://doi.org/10.17265/2161$623 \mathrm{x} / 2018.03 .003$

Baleghizadeh, S., \& Karamzade, T. (2017). Iranian EFL learners ' perceptions of various language activities in an ideal English class. MEXTESOL Journal, 41(1), 1-15. http://mextesol.net/journal/public/files/b51fab6 cc17b8acc8881e7244a99eb8f.pdf

Botvinick, M., \& Braver, T. (2015). Motivation and cognitive control: From behavior to neural mechanism. Annual Review of Psychology, 66, 83-113. https://doi.org/10.1146/annurevpsych-010814-015044

Brown, H. D. (1994). Teaching by principles: An interactive approach to language pedagogy. Prentice Hall Regents.

Cambridge English Language Assessment. (2016). English at Work: global analysis of language skills in the workplace. http://englishatwork.cambridgeenglish.org/

Chowdhury, T. A. (2020). Towards Consistent and fair assessment practice of students' subjective writing. International Journal of Linguistics and Translation Studies, 1(1), 32-41. https://doi.org/10.36892/ijlts.v1i1.14

Chowdhury, T. A., \& Haider, M. Z. (2012). A needbased evaluation of the EAP courses for the pharmacy students in the university of Asia Pacific (UAP), Bangladesh. Asian Social Science, 8(15), 93-107. https://doi.org/10.5539/ass.v8n15p93

Clement, R., Dornyei, Z., \& Noels, K. A. (1994). Motivation, self-confidence, and group cohesion in the foreign language classroom. Language Learning, 44(3), 417-448. http://citeseerx.ist.psu.edu/viewdoc/download? doi=10.1.1.681.9589\&rep=rep1\&type=pdf

Cohen, D. K., \& Bhatt, M. P. (2012). The importance of infrastructure development to high-quality literacy instruction. Future of Children, 22(2), 117-138. https://doi.org/10.1353/foc.2012.0012
Ellis, R. (1994). The study of second language acquisition. Oxford University Press.

Ellis, R. (1997). SLA Research and Language Teaching. Oxford University Press, 198 Madison Avenue, New York, NY 10016-4314. http://www.oup-usa.org

Emler, T. E., Zhao, Y., Deng, J., Yin, D., \& Wang, Y. (2019). Side effects of large-scale assessments in education. ECNU Review of Education, 2(3), 279-296. https://doi.org/10.1177/2096531119878964

Erling, E. J. (2017). Language planning, English language education and development aid in Bangladesh. Current Issues in Language Planning, 18(4), 388-406. https://doi.org/10.1080/14664208.2017.133149 6

Gardner, R. C. (2010). Motivation and second language acquisition: The socio-educational model. Peter Lang, New York.

Gardner, R. C., \& Lambert, W. E. (1972). Attitudes and motivation in second language learning. Newburry.

Green, P. I., Finkel, E. J., Fitzsimons, G. M., \& Gino, F. (2017). The energizing nature of work engagement: Toward a new need-based theory of work motivation. Research in Organizational Behavior, 37, 1-18. https://doi.org/10.1016/j.riob.2017.10.007

Hamid, M. O. (2011). Globalisation, English for everyone and English teacher capacity: Language policy discourses and realities in Bangladesh. Current Issues in Language Planning, 11(4), 289-310. https://doi.org/10.1080/14664208.2011.532621

Hamid, M. O., \& Erling, E. J. (2016). English-inEducation policy and planning in Bangladesh: A critical examination. In R. Kirkpatric (Ed.), English Language Education Policy in Asia (Vol. 11, pp. 25-48). Springe, Cham. https://doi.org/10.1007/978-3-319-22464-0_2

Haque, M. M. (2017). "Needs Analysis": A tertiary level EAP course in Bangladesh. Crossings: ULAB Journal of English Studies, 8, 225-236. https://sah.ulab.edu.bd/wpcontent/uploads/sites/3/2016/03/CrossingsVol.-8_Published.pdf\#page $=225$

Harlen, W. (2012). The role of assessment in developing motivation for learning. In J. Gardner (Ed.), Assessment and Learning (pp. 171-184). SAGE Publication Ltd. https://doi.org/10.4135/9781446250808.n11

Hornstra, L., Mansfield, C., van der Veen, I., Peetsma, T., \& Volman, M. (2015). Motivational teacher strategies: the role of beliefs and contextual factors. Learning Environments Research, 18(3), 363-392. https://doi.org/10.1007/s10984-015-9189-y 
Irvin, J. L., Meltzer, J., \& Dukes, M. (2007). Taking action on adolescent literacy: An implementation guide for school leaders. Ascd.

Jianfeng, C., Raj, G. S., \& Ai, J. T. T. (2018). The correlations among learning motivation, autonomy and language proficiency in Chinese EFL context. LEARN Journal: Language Education and Acquisition Research Network Journal, 11(1), 1-14.

Kaur, N. (2014). Autonomous language learning behaviour: The role of instructional mediation in vocabulary development. Pertanika Journal of Social Science and Humanities, 22(2), 589603.

http://www.pertanika.upm.edu.my/\%0AAuton omous

Kaur, N. (2017). The role of peers and cultural tools in supporting autonomous learning behaviours among Malay tertiary learners. Pertanika Journal of Social Sciences and Humanities, 25(1), 61-80. http://www.pertanika.upm.edu.my/

Khan, H. R., \& Rahaman, A. (2017). Do English language teacher qualities affect student performance?: an explanatory study from Bangladesh. Malaysian Journal of ELT Research, 13(1), 13-29.

http://journals.melta.org.my/index.php/majer/a rticle/view/396/279

Khan, N. T. (2019). Effectiveness of EAP courses in private universities of Bangladesh [Brac University].

http://dspace.bracu.ac.bd/xmlui/handle/10361/ 13667

Khan, R., Bashir, A., Basu, B. L., \& Uddin, M. E. (2020). Emergency online instruction at higher education in Bangladesh during COVID-19: challenges and suggestions. Journal of Asia TEFL, 17(4), 1497-1506. https://doi.org/10.18823/asiatefl.2020.17.2.10. 463

Khonamri, F., Molana, K., Danaei, M., Kazemian, M., \& Lecturer, E. (2020). Indeffatigable willingness to accomplish objectives: The relationship between EFL learners' motivation and autonomy. JOLLT Journal of Languages and Language Teaching, 8(4), 422-431. https://doi.org/10.33394/jollt.v\%vi\%i.2960

Kimmerle, J., Moskaliuk, J., Oeberst, A., \& Cress, U. (2015). Learning and collective knowledge construction with social media: A processoriented perspective. Educational

Psychologist, 50(2), 120-137. https://doi.org/10.1080/00461520.2015.103627 3

Kirkpatrick, R., \& Zang, Y. (2011). The negative influences of exam-oriented education on Chinese high school students: Backwash from lassroom to child. Language Testing in Asia,
1(3), 36-45. https://doi.org/10.1186/2229-

0443-1-3-36

Kolb, D. A. (1984). Experiential learning:

Experience as the Source of learning and development. Prentice-Hall.

Kuyyogsuy, S. (2019). Promoting peer feedback in developing students' English writing ability in L2 writing class. International Education Studies, 12(9), 76-90. https://doi.org/10.5539/ies.v12n9p76

Lai, H. Y. T. (2013). The motivation of learners of english as a foreign language revisited. International Education Studies, 6(10), 90101. https://doi.org/10.5539/ies.v6n10p90

Lathif, M. (2017). Investigating non-English department students' motivation in EFL writing. International Journal of Indonesian Education and Teaching, 1(1), 32-41. http://ejournal.usd.ac.id/index.php/IJIET

Lavrakas, P. J. (2015). Encyclopedia of survey research methods (Vols. 1-0). Thousand Oaks, CA: Sage Publications, Inc. https://dx.doi.org/10.4135/9781412963947.n35 2

Liu, H. (2015). Learner autonomy: The role of motivation in foreign language learning. Journal of Language Teaching and Research, 6(6), 1165-1174. https://doi.org/10.17507/jltr.0606.02

Lodhi, M. A., Sahar, A. H., Qayyum, N., Iqbal, S., \& Shareef, H. (2019). Relationship of school environment and English language learning at government schools. Public Administration Research, 8(1), 1. https://doi.org/10.5539/par.v8n1p1

Loganthan, S., \& Zafar, S. (2016). Motivation in second language learning - A retrospect. GALAXY International Interdisciplinary Research Journal, 4(1), 7-13.

MacIntyre, P. D., K, M., \& Baker, S. C. (2001). The convergence of multiple models of motivation for second language learning: Gardner, Pintrich, Kuhl, and McCroskey. In Z. Dornyei \& R. Schmidt (Eds.), Motivation and second language acquisition (Technical Report 23) (pp. 461-492). Honolulu: University of Hawai, Second Language Teaching and Curriculum Center.

Mak, P., \& Wong, K. M. (2017). Self-regulation through portfolio assessment in writing classrooms. ELT Journal, 72(1), 49-61. https://doi.org/10.1093/elt/ccx012

Mallik, S. (2017). Motivation as a promoting determinant in second and foreign language classroom: A review. European Journal of Foreign Language Teaching, 2(1), 90-102. https://doi.org/10.5281/zenodo.293024

Mamun, M. A. Al., \& Rahman, M. M. (2017). An analysis of academic needs of the English Department students of Bangladeshi 
universities. Journal of Jessore University of Science and Technology, 2(1), 1-11. https://www.researchgate.net/profile/Md_Abdu llah_Mamun9/publication/325683109

Melitz, J. (2018). English as a lingua franca: Facts, benefits and costs. World Economy, 41(7), 125. https://doi.org/10.1111/twec.12643

Morris, T. H. (2020). Experiential learning-a systematic review and revision of Kolb's model. Interactive Learning Environments, 28(8), 1064-1077. https://doi.org/10.1080/10494820.2019.157027 9

Muslim, A. B., Hamied, F. A., \& Sukyadi, D. (2020). Integrative and instrumental but low investment: The English learning motivation of Indonesian senior high school students. Indonesian Journal of Applied Linguistics, 9(3), 493-507. https://doi.org/10.17509/ijal.v9i3.23199

Nguyen, X. N. C. M. \& Walkinshaw, I. (2018). Autonomy in teaching practice : Insights from Vietnamese English language teachers trained in Inner-Circle countries. Teaching and Teacher Education, 69, 21-32. https://doi.org/10.1016/j.tate.2017.08.015

Nurbaety, N. U., \& Hartini, N. (2020). Exploring students' motivation in EFL classroom. VEL, I(January).

Purmama, N. A., Rahayu, N. S., \& Yugafiati, R. (2019). Students' motivation in learning English. PROJECT Professional Journal of English Education, 2(4), 539-544. https://www.researchgate.net/publication/3372 49596_Students\%27_Motivation_in_Learning English

Quadir, M. (2017). Let us listen to our students : an analysis of demotivation to study english in Bangladesh. The English Teacher, 46(3), 128141.

Rahman, M. M., Islam, M. S., Karim, A., Chowdhury, T. A., Rahman, M. M., Seraj, P. M. I., \& Singh, M. K. M. (2019). English language teaching in Bangladesh today: Issues, outcomes and implications. Language Testing in Asia, 9(9), 1-14. https://doi.org/10.1186/s40468-019-0085-8

Rahman, S. (2005). Orientations and motivation in English language learning: A study of Bangladeshi students at undergraduate level. Asin EFL Journal, 7(1), 1-26. https://asian-efljournal.com/March_2005_EBook_editions.pdf \#page $=29 \%$ Ahttp://www.asian-efljournal.com

Riswanto, A., \& Aryani, S. (2017). Learning motivation and student achievement : description analysis and relationships.
COUNS-EDU: The International Journal of Counseling and Education, 2(1), 42-47. https://doi.org/10.23916/002017026010

Riya, R. R., \& Kabir, M. M. N. (2019). Usefulness of English foundation courses : A study on private universities in Bangladesh.

Manababidya Gabesanapatra, 3(July 2019), 369-393.

file://C:/Users/User/Downloads/Usefulnessof EnglishFoundationCoursesRiya_Kabir.pdf

Ryan, R. M., \& Deci, E. L. (2020). Intrinsic and extrinsic motivation from a self-determination theory perspective: Definitions, theory, practices, and future directions. Contemporary Educational Psychology, 61(April), 101860. https://doi.org/10.1016/j.cedpsych.2020.10186 0

Saha, S. (2017). EFL students' 'Unmotivation' toward writing classroom : Bangladeshi university teachers' narrative reflections. BELTA Journal, 1(1), 46-63. https://doi.org/10.36832/beltaj.2017.0101.03\% OAEFL

Soberg, P. (2018). Reflective learning : Fostering motivation, metacognition, and autonomy, and raising language learning strategy awareness [University of Wisconsin-River Falls]. https://minds.wisconsin.edu/handle/1793/7879 6

Taherdoost, H. (2019). What is the best response scale for survey and questionnaire design: Review of different lengths of rating Scale/ attitude scale / likert Scale. International Journal of Academic Research in Management (IJARM), 8(1), 1-10. www.elvedit.com

The Center for Development and Learning. (n.d.). Understanding The Learning Process To Effectively Differentiate Instruction. Retrieved January 6, 2021, from https://www.cdl.org/understanding-thelearning-process-to-effectively-differentiateinstruction/

UNESCO. (2020). Startling digital divides in distance learning emerge. https://en.unesco.org/news/startling-digitaldivides-distance-learning-emerge

Vésteinsdóttir, V., Joinson, A., Reips, U. D., Danielsdottir, H. B., Thorarinsdottir, E. A., \& Thorsdottir, F. (2019). Questions on honest responding. Behavior Research Methods, 51(2), 811-825. https://doi.org/10.3758/s13428-018-1121-9

Zhao, Y. (2020). COVID-19 as a catalyst for educational change. Prospects, 49(1-2), 2933. https://doi.org/10.1007/s11125-020-09477$\mathrm{y}$ 


\section{APPENDIX}

\section{Student Interview Questionnaire}

1. How do you judge your level of English?

2. What is your reason for attending the English language courses? Would you elaborate on that?

3. Do you think your English language courses can develop your skills you require? Would you elaborate on that?

4. Do you enjoy the way your teachers deliver the courses? Is there anything you would like to add?

5. Do enjoy the course materials and the tasks used in the course? Do you face any challenges in accessing them? 